\title{
DO TIME MANAGEMENT FACTORS IMPEDE STUDENTS' ACADEMIC ACHIEVEMENT? : A CASESTUDY - SOHAR UNIVERSITY, OMAN
}

Farooq Salman Alani ${ }^{1 *}$, Firdouse Rahman Khan ${ }^{2}$, Abdulrazzaq Tuama Hawas ${ }^{3}$

${ }^{1 *}$ Al-Rafidain University College, Global Humanistic University, Iraq; ${ }^{2}$ Faculty of Business, Sohar University, Oman;

${ }^{3}$ Accounting Department, Al-Rafidain University College, Iraq. Email: ${ }^{1 *}$ frqalani2013@yahoo.com, ${ }^{2}$ firdouse4u@yahoo.co.uk, ${ }^{3}$ razzaqhawas1964@gmail.com

Article History: Received on $3^{\text {rd }}$ June 2020, Revised on $30^{\text {th }}$ June 2020, Published on $15^{\text {th }}$ July 2020

\begin{abstract}
Purpose: The objective of the research study is to critically analyze the factors impeding time management towards students' academic performance achievement.

Design/methodology/approach: The study was carried out using a well-defined questionnaire collecting samples from 164 undergraduate students studying in the Faculty of Business, Sohar University, Sultanate of Oman from a population of 700 undergraduate students. For the study, the cluster-sampling method was adopted. SPSS was used to perform the statistical analysis.
\end{abstract}

Findings: The empirical results reveal that none of the claimed factors related to time management influence the academic performance of the students. The students' performance is purely based on their efforts and on their own self-management. Thus, it was concluded that it is the responsibility of the students to manage their time for which they should make their own plans.

Practical Implications: The study confirms that the student's stay at the hostel facilitates them to improve their academic performances. It is also interpreted that the students are carried away by the domestic work during their stay at home, parents should take utmost not to deprived of their time for study. Parents should make necessary arrangements to reduce their travel time. Students should have their own self-control and self-commitment to manage and plan their own time for study purposes.

Originality/value: The research work is of its first kind as it focuses on the impact of time management factors on the academic performances of the students.

Keywords: Time Management Factors, Personal Interest Factors, Social Factors, Self-Planning Factors, Hostel, Transportation, University Related factors, Academic Performance.

\section{INTRODUCTION}

God has vested upon humanity, an invaluable resource viz. the time which is equally given to everyone, without any partiality. Poor or rich, black or white, everyone has exactly 24 hours. In these 24 hours, each one has many things to do, indeed everyone struggles to manage their time. In the case of students, the issue is more complicated as they are connected and committed to so many activities interlinked to family, home, society, work, and studies. Time is an invaluable source and that cannot be retrieved or altered. Therefore, time management is an essential function to be looked into.

Time Management is the science and art of planning and organizing time between the activities towards achieving the goals and in completing daily tasks. Time management is defined as the behavior which aims at effectively using the time to complete goal-oriented activities (Claessens, Van Eerde, Rutte, \& Roe, 2007). Time management aims to at estimating the time required to carry out and complete the activities, efficiently.

The art of time management skills has a significant impact on students' academic performances too (Al-Zoubi, 2016; Dalli, 2014; Macan, Shahani, Dipboye, \& Phillips, 1990; Olowookere, Alao, Odukoya, Adekeye, \& Agbude, 2015; Oyuga, Raburu, \& Aloka, 2016). Academic achievement is the result of the successful completion of assessments and the final examination. Good academic achievement every student aims at and is referred by his/her grade. Good time management can lead to good academic performance (Hamzah, Lucky, \& Joarder, 2014). Indeed, there is a direct relationship between time management, self-esteem, and GPA (Eid, Safan, \& Diab, 2015; Zulauf \& Gortner, 1999). Motivation, time management behaviors, and beliefs may have an impact on academic achievement (Nonis \& Hudson, 2006; Wells, 1994). Students have to realize the importance of time management and their perception of time management is very important in relates to either curricular or co-curricular activities (Twehues, 2013).

\section{Importance of the study}

To excel successfully with good academic performance, it is essential for the students to adopt time management techniques. People use different ways and means to manage their time to be more productive. Some people have the skills to manage 
their time well. Indeed, there are some strategies and techniques to manage time towards success. Time management makes a positive impact on academic achievement and negatively due to the time spent on social media (Adebayo, 2015). In the early days of joining a university or college, students are too careless in managing their time. They waste time in unwanted activities, which are no way beneficial to them, academically. Students should be aware of time wastage and should take responsibility for managing the time more efficiently by increasing the awareness of their attitudes, planning, thinking, and behaviors (Gayef, Tapan, \& Sur, 2017). Effective time management leads to greater academic performance and at the same time brings down the levels of anxiety and stress in students (Adams \& Blair, 2019; Al Khatib, 2014).

Though the students realize the importance of time management, they do not pay attention to it. Some of the authors even claimed that the practice of time management has no effect on academic achievement as far as students are concerned (Hamdan, Nasir, Khairudin, \& Sulaiman, 2014; Swart, Lombard, \& de Jager, 2010). Therefore, it becomes essential to find out the reason for such negligence and thus the reason behind the study. Therefore, the objective of the study is to critically analyze the factors impeding time management towards students' academic performance achievement.

\section{REVIEW OF LITERATURE}

Though time management is beneficial to the students in increasing their academic performance achievement, there are certain factors, which impede them in managing their time.

\section{Hostel}

Students' time management skills revealed that the performance of the students living in hostels were higher than the day scholars (Karakose, 2015). Quite and calm undisturbed study environment, and uninterrupted availability of power supply and other facilities in the hostel, allowed the students to manage and spend more time and manage their studies (Zotorvie, 2017). Mostly, students staying in hostel get plenty of time, most of which they spend studying; at the same time as there is no monitoring, they waste half of it on social media and chat (Mohamed, Hamal, \& Mohamed, 2018). Hostel students with necessary facilities showed a great improvement in their academic performances as they felt comfortable spending their time on studies (Mansoor \& Hussain Ali, 2015). Noticeable differences in academic performance of the students living in a hostel were observed as they reported they got plenty of time to study (Adeel, 2018). The hostel students were confident, realistic, time responsible, and sharp in their academics (Iftikhar \& Ajmal, 2015). In particular, female students staying in hostel properly manage their time, study effectively, and achieve higher academic performances (Khurshid, Tanveer, \& Qasmi, 2012).

\section{Transportation}

The academic performances of the day scholar students are lower than those living at their home due to the loss of time in travel, and the students are not able to cope up with their studies (Ahmad, Shahid, \& Banu, 2018). Students commuting daily has to face increasing burdens on their daily lives and to cope up with the time management (Forbus, Newbold, \& Mehta, 2011) whereas students living in hostel were able to spend more time on their private studies, assignments and were able to save their transportation time (Zakaria, 2016). Students preferred to save their commuting time and used it properly for study purposes (Khanam, Sahu, Rao, Kar, \& Quazi, 2017).

\section{Social Factors}

Parent/family distraction with mobile phones has become a regular incident while their wards are studying at home (McDaniel, 2019). Parenting behavior and their educational support could develop students' good learning behaviors thereby influencing the students' academic performance (Li \& Qiu, 2018). Family workload may highly impact students' academic achievement (Nzewi, Chiekezie, \& Ikon, 2016). The family role in supporting students in their daily life such as frequent contact of the family, level of parental financial support, independence from family are all important to the students' educational performance (DeFauw, Levering, Msipa, \& Abraham, 2018). Time spent in managing family affairs is a factor that disturbs the students' study time and hence the students claim that there is no time for the family (Zartler, 2010). Study time should be treated like an academic class free from the family and considered as a media-free zone (Office of the Famly Engagement, 2019). Students coming from families with good educational background try to cut off unnecessary social contacts during study hours including family affairs (Yörük, Boyraz, Akkuș, \& Akkuș, 2012). Mercanlioglu (2010) found that there is a difference between the performances of male and female as time management affectsacademic performance due to family responsibilities.

\section{Self-Planning Factors}

Self-planning has a direct influence on academic achievement (Dahie, Osman, \& Mohamed, 2015; Pehlivan, 2013). Students need to develop the skills to manage themselves as time management is nothing but self-management (Cyril, 2015). The usage of time by students is based on how effectively the students plan and manage themselves, their daily routine and activities, and schedule their study time so as to achieve their academic standards (Shazia Nasrullah \& Khan, 2015). Students 
do not design an efficient study plan which causes the failure of effective studies (Chanamarn \& Tamee, 2017). For the students struggling to balance between the academics and daily routines, a self-planning for study time is a must, to avoid anxiety and ineffective time management (Adams \& Blair, 2019). Adopting self-planning strategy, students avoid procrastination of daily studies leading to effective academic performances (Miqdadi, ALMomani, Masharqa, \& Elmousel, 2014). Orientation programs are needed for students to manage their time as an important component of self-regulated learning (Thibodeaux, Deutsch, Kitsantas, \& Winsler, 2017).

\section{Personal Interest Factors}

When the students' time management skills improve, their anxiety level decreases (Akcoltekin, 2015). The performance of a student is based on how one plan and divide the amount of time for the tasks and studies (Rai, 2016). Students should prioritize themselves between academic life, social life, and other life situations that may impede their academic achievements (Sikhakhane, 2019). Nowadays, the personal interest of the students is mostly towards social media as they are addicted to the internet and thus mismanage their time in unwanted activities (Chang, Liu, \& Lin, 2013; El Khatib \& Khan, 2017; Syed Nasrullah \& Khan, 2019).

\section{University-related factors}

The flexibility of a university environment and freedom can ruin students who have not learned the skills of time management (Razali, Rusiman, Gan, \& Arbin, 2017). Educational institutions should design the courses in such a way that student engagement and effective time management is ensured (Goodson, Miertschin, \& Stewart, 2016). Students face daily in their academic life, challenges such as academic stress and interpersonal relationships and solicited to focus group sessions for proper time management and coping strategies (Lin, Pan, \& Ching, 2015). Inefficient time management without proper guidance and counseling could lead to a decrease in students' academic performance (Britton \& Tesser, 1991; Hensley, Wolters, Won, \& Brady, 2018; Indreica, Cazan, \& Truta, 2011). A positive high progress could be achieved by the students only if the educational institution implements organized and timed lesson plans (Herrera Agudelo, 2016). University/College administration should build a cohesive strategy to develop a student's perception of time importance and time utilization in a fruitful manner (Alghaswyneh \& Basri, 2015). Teachers should pay attention to improving their time management skills as it impacts students' academic performance (Kayode \& Ayodele, 2015). Students provided with the lecture notes and handouts well before the class sessions were able to organize their time and prepare for their study, resulting in increased academic achievement (Erdemir \& Tomar, 2019).

After going through the above review of literature, the factors hostel related factors, transport-related factors, social factors, self-planning factors, personal interest factors and University-related factors were considered the major factors hindering the time management of the students.

\section{Hypotheses}

Therefore, it is claimed that the factors related to - Hostel, Transportation, Social factors, Self-planning, Personal interest, and University-related factors impede the time management of the students thereby the academic achievement of the students.

\section{RESEARCH METHODOLOGY}

The study was carried out using a well-defined questionnaire collecting samples from 164 undergraduate students of Sohar University in the Sultanate of Oman from a population of 700 undergraduate students from the Faculty of Business. For the study, the cluster-sampling method was adopted. Likert scale questions were used and the statistical analysis was carried out using SPSS.

\section{FINDINGS}

Table 1: Reliability Analysis of the data

\begin{tabular}{lll}
\hline & $\mathbf{N}$ & $\mathbf{\%}$ \\
\hline Valid Cases & 164 & 100.0 \\
Excluded & 0 & 0.0 \\
\hline
\end{tabular}

\begin{tabular}{ll}
\hline Cronbach's Alpha & N of items \\
\hline .860 & 31 items \\
\hline
\end{tabular}

The reliability analysis shows that the Cronbachs Alpha score $=0.860>0.70$. 
Table 2: Demographic details of the respondents

\begin{tabular}{|c|c|c|c|}
\hline \multicolumn{2}{|l|}{ Characteristics } & Frequency & $\%$ \\
\hline \multirow[t]{2}{*}{ Gender } & Male & 30 & 18.3 \\
\hline & Female & 134 & 81.7 \\
\hline \multirow{3}{*}{ Age } & $18-<20$ years & 25 & 39.1 \\
\hline & $20-<23$ years & 36 & 56.3 \\
\hline & $23-<25$ years & 3 & 4.7 \\
\hline \multirow{3}{*}{ Marital Status } & Single & 144 & 87.8 \\
\hline & Married & 19 & 11.6 \\
\hline & Widow/er & 1 & 0.6 \\
\hline \multirow{4}{*}{ Study Level } & Level 1 & 13 & 7.9 \\
\hline & Level 2 & 64 & 39.0 \\
\hline & Level 3 & 50 & 30.5 \\
\hline & Level 4 & 37 & 22.6 \\
\hline \multirow{2}{*}{ Employment Status } & Working & 15 & 9.1 \\
\hline & Not working & 149 & 90.9 \\
\hline \multirow{4}{*}{ Living in } & University Hostel & 25 & 15.2 \\
\hline & Private Hostel & 35 & 21.3 \\
\hline & Home with Family & 99 & 60.4 \\
\hline & Home with relative & 5 & 3.0 \\
\hline \multirow{3}{*}{ Size of the family } & Big Family & 52 & 31.7 \\
\hline & Small Family & 47 & 28.7 \\
\hline & Missing & 65 & 39.6 \\
\hline \multirow{3}{*}{ Transportation } & Walking & 28 & 17.1 \\
\hline & Car & 55 & 33.5 \\
\hline & Bus & 81 & 49.4 \\
\hline \multirow{4}{*}{$\begin{array}{l}\text { Travel time to reach } \\
\text { home/hostel }\end{array}$} & $<30$ Minutes & 94 & 57.3 \\
\hline & 30 Minutes $-<1$ hour & 36 & 22.0 \\
\hline & 1 -2hours & 32 & 19.5 \\
\hline & More than 2 hours & 2 & 1.2 \\
\hline \multirow{3}{*}{ GPA } & $<2$ & 30 & 18.3 \\
\hline & $2-3$ & 105 & 64.0 \\
\hline & $3-4$ & 29 & 17.7 \\
\hline
\end{tabular}

Source: Questionnaire

Personal factors

Table 3: Personal Interest factors

\begin{tabular}{|c|c|c|c|c|c|c|c|c|c|}
\hline$\#$ & Statement & Never & Rarely & $\begin{array}{l}\text { Someti } \\
\text { mes }\end{array}$ & Often & Always & $\begin{array}{l}\text { K-S } \\
\text { Value }\end{array}$ & $\begin{array}{l}\text { Chi- } \\
\text { Square }\end{array}$ & $\begin{array}{l}\mathbf{p} \\
\text { value }\end{array}$ \\
\hline 1 & $\begin{array}{l}\text { Take responsibility of my } \\
\text { time }\end{array}$ & $\begin{array}{l}5 \\
3.0 \%\end{array}$ & $\begin{array}{l}12 \\
7.3 \%\end{array}$ & $\begin{array}{l}45 \\
27.4 \%\end{array}$ & $\begin{array}{l}38 \\
23.2 \%\end{array}$ & $\begin{array}{l}64 \\
39.0 \%\end{array}$ & 3.009 & 71.793 & .000 \\
\hline 2 & $\begin{array}{l}\text { Finding difficulty following } \\
\text { own plans }\end{array}$ & $\begin{array}{l}6 \\
3.7 \%\end{array}$ & $\begin{array}{l}21 \\
12.8 \%\end{array}$ & $\begin{array}{l}80 \\
48.8 \%\end{array}$ & $\begin{array}{l}54 \\
32.9 \%\end{array}$ & $\begin{array}{l}3 \\
1.8 \%\end{array}$ & 3.262 & 134.841 & .000 \\
\hline 3 & $\begin{array}{l}\text { Having a clear idea of the } \\
\text { daily routine }\end{array}$ & $\begin{array}{l}6 \\
3.7 \%\end{array}$ & $\begin{array}{l}16 \\
9.8 \%\end{array}$ & $\begin{array}{l}43 \\
26.2 \%\end{array}$ & $\begin{array}{l}52 \\
31.7 \%\end{array}$ & $\begin{array}{l}47 \\
28.7 \%\end{array}$ & 2.623 & 51.061 & .000 \\
\hline 4 & Able to avoid distractions & $\begin{array}{l}6 \\
3.7 \% \\
\end{array}$ & $\begin{array}{l}29 \\
17.7 \% \\
\end{array}$ & $\begin{array}{l}67 \\
40.9 \% \\
\end{array}$ & $\begin{array}{l}45 \\
27.4 \% \\
\end{array}$ & $\begin{array}{l}17 \\
10.4 \% \\
\end{array}$ & 2.756 & 70.146 & .000 \\
\hline 5 & I avoid procrastination & $\begin{array}{l}8 \\
4.9 \% \\
\end{array}$ & $\begin{array}{l}32 \\
19.5 \% \\
\end{array}$ & $\begin{array}{l}58 \\
35.4 \% \\
\end{array}$ & $\begin{array}{l}45 \\
27.4 \% \\
\end{array}$ & $\begin{array}{l}21 \\
12.8 \% \\
\end{array}$ & 2.384 & 46.915 & .000 \\
\hline 6 & $\begin{array}{l}\text { I am able to say no to things } \\
\text { that waste my time }\end{array}$ & $\begin{array}{l}9 \\
5.5 \% \\
\end{array}$ & $\begin{array}{l}34 \\
20.7 \% \\
\end{array}$ & $\begin{array}{l}55 \\
33.5 \%\end{array}$ & $\begin{array}{l}44 \\
26.8 \% \\
\end{array}$ & $\begin{array}{l}22 \\
13.4 \% \\
\end{array}$ & 2.270 & 39.720 & .000 \\
\hline
\end{tabular}


7 Complete my assessments

within the deadline

$\begin{array}{lllllll}2 & 23 & 58 & 51 & 30 & 2.614 & 61.549 \\ 1.2 \% & 14.0 \% & 35.4 \% & 31.1 \% & 18.3 \% & & \end{array}$

.000

Null Hypothesis1 There is no relationship between Personal factors and the choices of the respondents.

It can be observed from Table 3 that the p-value is less than 0.05 for all the factors i.e. null hypothesis 1 gets rejected which indicates that there is a relationship between the Personal factors and the choices of the respondents. Comparing the K-S values obtained from the Kolmogorov-Smirnov test, it is observed that 'Finding difficult to follow my own plans (3.262)'ranked first, followed by 'Take the responsibility of my time (3.009)' and 'Able to avoid distractions (2.756)'.

\section{Social factors}

Table 4: Social factors

\begin{tabular}{|c|c|c|c|c|c|c|c|c|c|}
\hline \# & Statement & Never & Rarely & $\begin{array}{l}\text { Some } \\
\text { times }\end{array}$ & Often & Always & $\begin{array}{l}\text { K-S } \\
\text { Value }\end{array}$ & $\begin{array}{l}\text { Chi- } \\
\text { Square }\end{array}$ & $\begin{array}{l}\mathbf{p} \\
\text { value }\end{array}$ \\
\hline 1 & $\begin{array}{l}\text { Get enough time to study at } \\
\text { home }\end{array}$ & $\begin{array}{l}27 \\
16.5 \%\end{array}$ & $\begin{array}{l}28 \\
17.1 \%\end{array}$ & $\begin{array}{l}40 \\
24.4 \%\end{array}$ & $\begin{array}{l}36 \\
22.0 \%\end{array}$ & $\begin{array}{l}33 \\
20.1 \%\end{array}$ & 2.067 & 3.622 & .460 \\
\hline 2 & $\begin{array}{l}\text { My study plans } \\
\text { affected by my family }\end{array}$ & $\begin{array}{l}49 \\
29.9 \%\end{array}$ & $\begin{array}{l}29 \\
17.7 \%\end{array}$ & $\begin{array}{l}45 \\
27.4 \%\end{array}$ & $\begin{array}{l}29 \\
17.7 \%\end{array}$ & $\begin{array}{l}12 \\
7.3 \%\end{array}$ & 2.369 & 26.610 & .000 \\
\hline 3 & $\begin{array}{l}\begin{array}{l}\text { Spend more time on } \\
\text { domestic works }\end{array} \\
\end{array}$ & $\begin{array}{l}16 \\
9.8 \%\end{array}$ & $\begin{array}{l}32 \\
19.5 \% \\
\end{array}$ & $\begin{array}{l}66 \\
40.2 \% \\
\end{array}$ & $\begin{array}{l}28 \\
17.1 \% \\
\end{array}$ & $\begin{array}{l}22 \\
13.4 \% \\
\end{array}$ & 2.717 & 46.488 & .000 \\
\hline 4 & $\begin{array}{l}\text { Phone calls from my } \\
\text { family \& friends takes lots } \\
\text { of my time }\end{array}$ & $\begin{array}{l}62 \\
37.8 \%\end{array}$ & $\begin{array}{l}50 \\
30.5 \%\end{array}$ & $\begin{array}{l}24 \\
14.6 \%\end{array}$ & $\begin{array}{l}17 \\
10.4 \%\end{array}$ & $\begin{array}{l}11 \\
6.7 \%\end{array}$ & 3.073 & 59.476 & .000 \\
\hline
\end{tabular}

Null Hypothesis 2 There is no relationship between Social factors and the choices of the respondents.

It can be observed from table No.4 that the p-value is less than 0.05 for all the factors except the first statement. So the table obtained after eliminating the first factor from table No.4 can be considered as rejecting Null hypothesis2, which indicates there is a relationship between Social factors and the choices of the respondents. Comparing the K-S values obtained from Kolmogorov-Smirnov test, it is observed that 'Phone calls from family \& friends take lots of my time (3.073)' ranked first, followed by 'I spend more time on domestic works (2.717)' and 'My study plans get affected by my family (2.369)'.

\section{Planning and Organizing}

Table 5: Self-Planning Factors

\begin{tabular}{|c|c|c|c|c|c|c|c|c|c|}
\hline \# & Statement & Never & Rarely & $\begin{array}{l}\text { Some } \\
\text { times }\end{array}$ & Often & Always & $\begin{array}{l}\text { K-S } \\
\text { Value }\end{array}$ & $\begin{array}{l}\text { Chi- } \\
\text { Square }\end{array}$ & $\begin{array}{l}\mathbf{p} \\
\text { value }\end{array}$ \\
\hline 1 & $\begin{array}{l}\text { Daily prepare the list of } \\
\text { things to do }\end{array}$ & $\begin{array}{l}19 \\
11.6 \%\end{array}$ & $\begin{array}{l}39 \\
23.8 \%\end{array}$ & $\begin{array}{l}48 \\
29.3 \%\end{array}$ & $\begin{array}{l}37 \\
22.6 \%\end{array}$ & $\begin{array}{l}21 \\
12.8 \%\end{array}$ & 1.966 & 18.805 & .001 \\
\hline 2 & $\begin{array}{l}\text { Use strategies to } \\
\text { manage my time }\end{array}$ & $\begin{array}{l}10 \\
6.1 \%\end{array}$ & $\begin{array}{l}43 \\
26.2 \%\end{array}$ & $\begin{array}{l}64 \\
39.0 \%\end{array}$ & $\begin{array}{l}27 \\
16.5 \%\end{array}$ & $\begin{array}{l}20 \\
12.2 \%\end{array}$ & 2.848 & 54.720 & .000 \\
\hline 3 & $\begin{array}{l}\text { In daily plan allotting } \\
\text { some free time for } \\
\text { relaxation }\end{array}$ & $\begin{array}{l}9 \\
5.5 \%\end{array}$ & $\begin{array}{l}9 \\
5.5 \%\end{array}$ & $\begin{array}{l}44 \\
26.8 \%\end{array}$ & $\begin{array}{l}45 \\
27.4 \%\end{array}$ & $\begin{array}{l}57 \\
34.8 \%\end{array}$ & 2.566 & 60.756 & .000 \\
\hline 4 & $\begin{array}{l}\text { Plan and prioritize my } \\
\text { tasks }\end{array}$ & $\begin{array}{l}0 \\
0 \%\end{array}$ & $\begin{array}{l}20 \\
12.2 \%\end{array}$ & $\begin{array}{l}52 \\
31.7 \%\end{array}$ & $\begin{array}{l}45 \\
27.4 \%\end{array}$ & $\begin{array}{l}47 \\
28.7 \%\end{array}$ & 2.594 & 14.976 & .002 \\
\hline 5 & $\begin{array}{l}\text { Daily, I cross-check my } \\
\text { completed tasks against } \\
\text { my plan }\end{array}$ & $\begin{array}{l}18 \\
11.0 \%\end{array}$ & $\begin{array}{l}40 \\
24.4 \%\end{array}$ & $\begin{array}{l}48 \\
29.3 \%\end{array}$ & $\begin{array}{l}34 \\
20.7 \%\end{array}$ & $\begin{array}{l}24 \\
14.6 \%\end{array}$ & 2.028 & 17.707 & .001 \\
\hline 6 & $\begin{array}{l}\text { Daily I follow-up with } \\
\text { my checklist }\end{array}$ & $\begin{array}{l}37 \\
22.6 \% \\
\end{array}$ & $\begin{array}{l}42 \\
25.6 \%\end{array}$ & $\begin{array}{l}48 \\
29.3 \% \\
\end{array}$ & $\begin{array}{l}25 \\
15.2 \%\end{array}$ & $\begin{array}{l}12 \\
7.3 \% \\
\end{array}$ & 2.181 & 25.207 & .000 \\
\hline
\end{tabular}

Null Hypothesis 3 There is no relationship between Planning and Organizing and the choices of the respondents.

It can be observed from Table5, that the p-value is less than 0.05 i.e. null hypothesis 3 gets rejected, which indicates that there is a relationship between Planning and Organizing and the choices of the respondents. Comparing the K-S values 
obtained from Kolmogorov-Smirnov test, it is observed that 'Use strategies to manage my time' (2.848) is ranked first, followed by 'Plan and prioritize my tasks' (2.594) and 'In daily plan allotting some free time for relaxation' (2.566).

Hostel

Table 6: Hostel

\begin{tabular}{|c|c|c|c|c|c|c|c|c|c|}
\hline \# & Statement & Never & Rarely & $\begin{array}{l}\text { Some } \\
\text { times }\end{array}$ & Often & Always & $\begin{array}{l}\text { K-S } \\
\text { Value }\end{array}$ & $\begin{array}{l}\text { Chi- } \\
\text { Square }\end{array}$ & $\begin{array}{l}\mathbf{p} \\
\text { value }\end{array}$ \\
\hline 1 & 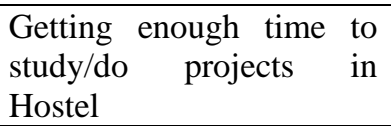 & $\begin{array}{l}4 \\
2.4 \%\end{array}$ & $\begin{array}{l}19 \\
11.6 \%\end{array}$ & $\begin{array}{l}18 \\
11.0 \%\end{array}$ & $\begin{array}{l}16 \\
9.8 \%\end{array}$ & $\begin{array}{l}8 \\
4.9 \%\end{array}$ & 1.469 & 13.538 & .009 \\
\hline 2 & $\begin{array}{l}\text { Facing distractions while } \\
\text { studying in hostel }\end{array}$ & $\begin{array}{l}7 \\
4.3 \% \\
\end{array}$ & $\begin{array}{l}12 \\
7.3 \% \\
\end{array}$ & $\begin{array}{l}27 \\
16.5 \% \\
\end{array}$ & $\begin{array}{l}13 \\
7.9 \%\end{array}$ & $\begin{array}{l}6 \\
3.7 \% \\
\end{array}$ & 1.720 & 21.692 & .000 \\
\hline 3 & $\begin{array}{l}\text { While in hostel able to } \\
\text { complete work in time }\end{array}$ & $\begin{array}{l}6 \\
3.7 \%\end{array}$ & $\begin{array}{l}9 \\
5.5 \%\end{array}$ & $\begin{array}{l}16 \\
9.8 \%\end{array}$ & $\begin{array}{l}26 \\
15.9 \%\end{array}$ & $\begin{array}{l}8 \\
4.9 \%\end{array}$ & 1.979 & 20.615 & .000 \\
\hline 4 & $\begin{array}{l}\text { Hostel environment is } \\
\text { suitable to study }\end{array}$ & $\begin{array}{l}10 \\
6.1 \% \\
\end{array}$ & $\begin{array}{l}9 \\
5.5 \% \\
\end{array}$ & $\begin{array}{l}19 \\
11.6 \%\end{array}$ & $\begin{array}{l}15 \\
9.1 \%\end{array}$ & $\begin{array}{l}12 \\
7.3 \% \\
\end{array}$ & 1.299 & 5.077 & .269 \\
\hline
\end{tabular}

Null Hypothesis4 There is no relationship between the hostel and the choices of the respondents.

It can be observed from Table 6, the p-value is less than 0.05 for all the factors except the fourth statement. So the table obtained after eliminating the fourth factor from Table No.6 can be considered as rejecting the Null hypothesis 4, which indicates that there is a relationship between Hostel and the choices of the respondents. Comparing the K-S values obtained from Kolmogorov-Smirnov test, it is observed from the choices of the responders that 'While in hostel able to complete work in time' (1.979) is ranked first, followed by 'Facing distractions while studying in the hostel' (1.720) and 'Getting enough time to study/do projects in Hostel' (1.469).

\section{Transportation}

Table 7: Transportation

\begin{tabular}{|c|c|c|c|c|c|c|c|c|c|}
\hline \# & Statement & Never & Rarely & $\begin{array}{l}\text { Some } \\
\text { times }\end{array}$ & Often & Always & $\begin{array}{l}\text { K-S } \\
\text { Value }\end{array}$ & $\begin{array}{l}\text { Chi- } \\
\text { Square }\end{array}$ & $\begin{array}{l}\text { p } \\
\text { value }\end{array}$ \\
\hline 1 & $\begin{array}{lcr}\begin{array}{l}\text { Study } \\
\text { affected } \\
\text { time }\end{array} & \text { by } & \text { gets } \\
\text { travel }\end{array}$ & $\begin{array}{l}34 \\
20.7 \%\end{array}$ & $\begin{array}{l}34 \\
20.7 \%\end{array}$ & $\begin{array}{l}52 \\
31.7 \%\end{array}$ & $\begin{array}{l}28 \\
17.1 \%\end{array}$ & $\begin{array}{l}16 \\
9.8 \%\end{array}$ & 2.140 & 20.634 & .000 \\
\hline 2 & $\begin{array}{l}\text { Traveling } \\
\text { university } \\
\text { home/hostel } \\
\text { lots of time }\end{array}$ & $\begin{array}{l}36 \\
22.0 \%\end{array}$ & $\begin{array}{l}37 \\
22.6 \%\end{array}$ & $\begin{array}{l}51 \\
31.1 \%\end{array}$ & $\begin{array}{l}25 \\
15.2 \%\end{array}$ & $\begin{array}{l}15 \\
9.1 \%\end{array}$ & 2.050 & 22.463 & .000 \\
\hline 3 & $\begin{array}{l}\text { Unable to plan study } \\
\text { time due to travel } \\
\text { arrangements }\end{array}$ & $\begin{array}{l}35 \\
21.3 \%\end{array}$ & $\begin{array}{l}41 \\
25.0 \%\end{array}$ & $\begin{array}{l}42 \\
25.6 \%\end{array}$ & $\begin{array}{l}32 \\
19.5 \%\end{array}$ & $\begin{array}{l}14 \\
8.5 \%\end{array}$ & 2.219 & 15.573 & .004 \\
\hline
\end{tabular}

Null Hypothesis5 There is no relationship between Transport and the choices of the respondents.

It can be observed from table.7, the p-value is less than 0.05 , which means that the null hypothesis gets rejected, which indicates that there is a relationship between Transport and the choices of the respondents. Comparing the K-S values obtained from Kolmogorov-Smirnov test, it is observed from the choices of the responders that 'Unable to plan study time due to travel arrangements' (2.219) is ranked first, followed by 'Study time gets affected by travel time' (2.140) and 'Traveling from university to home/hostel takes lots of time' (2.050).

\section{University-related factors}

Table 8: University-related factors

\begin{tabular}{|c|c|c|c|c|c|c|c|c|}
\hline Statement & Never & Rarely & $\begin{array}{l}\text { Someti } \\
\text { mes }\end{array}$ & Often & Always & $\begin{array}{l}\text { K-S } \\
\text { Value }\end{array}$ & $\begin{array}{l}\text { Chi- } \\
\text { Square }\end{array}$ & $\begin{array}{l}\text { p } \\
\text { value }\end{array}$ \\
\hline The teacher changed & 19 & 53 & 71 & 20 & 1 & & & \\
\hline $\begin{array}{l}\text { the due dates of } \\
\text { assessments }\end{array}$ & $11.6 \%$ & $32.3 \%$ & $43.3 \%$ & $12.2 \%$ & $.6 \%$ & 3.153 & 98.561 & .000 \\
\hline The changes in the & 21 & 42 & 55 & 30 & 16 & & & \\
\hline
\end{tabular}




\begin{tabular}{|c|c|c|c|c|c|c|c|c|}
\hline $\begin{array}{l}\text { due date of } \\
\text { assessment } \\
\text { submission affected } \\
\text { my plans }\end{array}$ & $12.8 \%$ & $25.6 \%$ & $33.5 \%$ & $18.3 \%$ & $9.8 \%$ & 2.219 & 30.695 & .000 \\
\hline $\begin{array}{l}\text { The events of the } \\
\text { university affected } \\
\text { my assessments dates }\end{array}$ & $\begin{array}{l}51 \\
31.1 \%\end{array}$ & $\begin{array}{l}38 \\
23.2 \%\end{array}$ & $\begin{array}{l}44 \\
26.8 \%\end{array}$ & $\begin{array}{l}21 \\
12.8 \%\end{array}$ & $\begin{array}{l}10 \\
6.1 \%\end{array}$ & 2.362 & 34.841 & .000 \\
\hline $\begin{array}{l}\text { Assessment due dates } \\
\text { are the same for all } \\
\text { the courses or almost } \\
\text { nearer }\end{array}$ & $\begin{array}{l}8 \\
4.9 \%\end{array}$ & $\begin{array}{l}27 \\
16.5 \%\end{array}$ & $\begin{array}{l}59 \\
36.0 \%\end{array}$ & $\begin{array}{l}39 \\
23.8 \%\end{array}$ & $\begin{array}{l}31 \\
18.9 \%\end{array}$ & 2.535 & 41.976 & .000 \\
\hline $\begin{array}{l}\text { I have back to back } \\
\text { exams }\end{array}$ & $\begin{array}{l}5 \\
3.0 \% \\
\end{array}$ & $\begin{array}{l}14 \\
8.5 \% \\
\end{array}$ & $\begin{array}{l}50 \\
30.5 \% \\
\end{array}$ & $\begin{array}{l}53 \\
32.3 \% \\
\end{array}$ & $\begin{array}{l}42 \\
25.6 \%\end{array}$ & 2.517 & 58.378 & .000 \\
\hline $\begin{array}{l}\text { There are many } \\
\text { assessments to do but } \\
\text { the time is lesser }\end{array}$ & $\begin{array}{l}6 \\
3.7 \%\end{array}$ & $\begin{array}{l}30 \\
18.3 \%\end{array}$ & $\begin{array}{l}78 \\
47.6 \%\end{array}$ & $\begin{array}{l}29 \\
17.7 \%\end{array}$ & $\begin{array}{l}21 \\
12.8 \%\end{array}$ & 3.401 & 89.110 & .000 \\
\hline $\begin{array}{l}\text { Lecture timings } \\
\text { allotted by the } \\
\text { university is suitable }\end{array}$ & $\begin{array}{l}15 \\
9.1 \%\end{array}$ & $\begin{array}{l}23 \\
14.0 \%\end{array}$ & $\begin{array}{l}57 \\
34.8 \%\end{array}$ & $\begin{array}{l}41 \\
25.0 \%\end{array}$ & $\begin{array}{l}28 \\
17.1 \%\end{array}$ & 2.277 & 33.195 & .000 \\
\hline
\end{tabular}

Null Hypothesis 6 There is no relationship between the university-related factors and the choices of the respondents.

From table No.8, it is observed that the p-value is less than 0.05 which means that the null hypothesis gets rejected which indicates that there is a relationship between the University related factors and the choices of the respondents. Comparing the $\mathrm{K}-\mathrm{S}$ values obtained from Kolmogorov-Smirnov test, it is observed that 'There are many assessments to do but the time is lesser' (3.401) is ranked first, followed by 'Teacher changed the due dates of assessments' (3.153) and 'Assessment due dates are same for all the courses or almost nearer' (2.535).

\section{Regression Analysis}

Table 9 (a), (b), (c) \& (d): Regression Analysis

\begin{tabular}{llll}
\hline Variables Entered/Removed & & \\
\hline & & Variables & \\
Model & Variables Entered & Removed & Method \\
\hline 1 & Personal Interest Factors, & \\
& Social Factors, Self-Planning & Enter \\
& Factors, Hostel, Transport, & \\
& University-related Factors & \\
\hline
\end{tabular}

a. Dependent Variable: Academic Performance

b. All requested variables entered.

\begin{tabular}{|c|c|c|c|c|}
\hline \multicolumn{5}{|c|}{ Model Summary } \\
\hline Model & $\mathrm{R}$ & R Square & $\begin{array}{l}\text { Adjusted } \\
\text { Square }\end{array}$ & $\begin{array}{l}\mathrm{R} \text { Std. Error of the } \\
\text { Estimate }\end{array}$ \\
\hline 1 & $.227^{\mathrm{a}}$ & .051 & -.047 & .578 \\
\hline
\end{tabular}

\begin{tabular}{lllllll}
\hline \multicolumn{2}{l}{ ANOVA } & \multicolumn{7}{l}{} \\
\hline Model & & Sum of Squares & df & Mean Square & F & Sig. \\
\hline \multirow{2}{*}{1} & Regression & 1.053 & 6 & .176 & .525 & $.787^{\mathrm{b}}$ \\
\cline { 2 - 7 } & Residual & 19.408 & 58 & .335 & & \\
\cline { 2 - 5 } & Total & 20.462 & 64 & & & \\
\hline
\end{tabular}


${ }^{a}$ Dependent Variable: Academic Performance

${ }^{\mathrm{b}}$ Predictors: (Constant), Personal Interest Factors, Social factors, Self-Planning factors, Hostel, Transportation, University-related Factors

\begin{tabular}{|c|c|c|c|c|c|}
\hline \multicolumn{6}{|l|}{ Coefficients } \\
\hline & \multicolumn{2}{|c|}{$\begin{array}{l}\text { Unstandardized } \\
\text { Coefficients }\end{array}$} & \multirow{2}{*}{$\begin{array}{l}\text { Standardized } \\
\text { Coefficients } \\
\text { Beta } \\
\end{array}$} & \multirow[b]{2}{*}{$\mathrm{t}$} & \multirow[b]{2}{*}{ Sig. } \\
\hline & B & Std. Error & & & \\
\hline (Constant) & 2.865 & .714 & & 4.012 & .000 \\
\hline $\begin{array}{ll}\text { Personal Interest } \\
\text { Factors }\end{array}$ & -.002 & .027 & -.013 & -.086 & .932 \\
\hline Social Factors & -.011 & .028 & -.053 & -.391 & .697 \\
\hline Self-Planning Factors & -.004 & .020 & -.033 & -.210 & .834 \\
\hline Hostel & .039 & .034 & .156 & 1.146 & .257 \\
\hline Transportation & -.028 & .025 & -.147 & $-\overline{1.096}$ & .277 \\
\hline $\begin{array}{l}\text { University-related } \\
\text { factors }\end{array}$ & .004 & .020 & .026 & .190 & .850 \\
\hline
\end{tabular}

${ }^{\mathrm{a}}$ Dependent Variable: Academic Performance

It can be seen from the F-table, that the p-value is .787 , which is greater than 0.05 , which clearly denotes that none of the variables (Personal interest factors, Social factors, Self-Planning factors, Hostel, Transport, and University-related factors) have any impact on the students' academic performance. i.e. there is no linear relationship between the variables - personal interest, social, Self-planning, Hostel, Transport and University-related factors and the Academic performance. In other words, the claimed hypothesis was disproved.

\section{DISCUSSION}

It was observed that most of the students living in their homes $(63.4 \%)$ complained that they have a time management problem.

Among the Personal interest factors, it was reported that they found it difficult to follow their own plans was the primary issue. However, they admitted that they take the responsibility for their own time and they try to avoid distractions.

Among the Social factors, the phone calls from family and friends take lots of their valuable time were their primary concern. They also confirmed that they spend more time on domestic works and their family affects their study plans. Among the Self-planning factors, they wished they use strategies to manage their time and they would like to plan and prioritize their tasks. Indeed, it was reported that amidst their daily schedule, they try to allot some free time for relaxation as well.

Among the Hostel related factors, they reported that they were able to complete their work in time while they were in the hostel, as they were having no distractions. They confirmed that they were getting enough time to study and do projects during their stay in the hostel.

Among the Transport related factors, they reported that they were unable to plan time for their studies due to travel arrangements and they feel wasting lots of time traveling from university to home/hostel and vice versa.

As far as the University related factors, they felt that most of their assessments were not given enough time and the due dates of assessments were changed by the teachers quite often and assessment due dates of most of the subjects were either clashes or almost nearer.

Further, it can be clearly seen that none of the factors -Personal Interest factors, Social factors, Self-Planning factors, Hostel related factors, Transport related factors and the University-related factors had any impact on the students' academic performance, which clearly indicates that the time management is independent of the above-claimed factors. 


\section{CONCLUSION}

From the above discussions, it can be concluded that none of the claimed factors related to time management influence the academic performance of the students i.e. academic performance has nothing to do with the claimed time management factors. In other words, the students' performance is purely based on their efforts and on their own self-management. However, it cannot be agreed that the wastage of time on various things will not hinder their studies. Thus, it becomes the responsibility of the students to manage their time, for which they should make their own plans.

\section{SUGGESTIONS}

Thus, the following suggestions are made:

1. Though the students get lots of time during their stay in the hostel, they should try to avoid distractions, keeping in mind the purpose of their stay, they need to focus on their studies to improve their academic performances.

2. It is quite natural that the students are carried away by the domestic work during their stay at home, parents should take the utmost care that they should not be deprived of the time for their study.

3. Parents should make necessary arrangements to reduce the travel time of the students so that the same can be properly utilized.

4. Besides all, the students should have their own self-control and self-commitment to manage and plan time on their own for study purposes and parental monitoring and guidance will motivate them to improve their academic performances.

\section{REFERENCES}

1. Adams, R. V., \& Blair, E. (2019). Impact of time management behaviors on undergraduate engineering students' performance. SAGE Open, 9(1), 1-11. https://doi.org/10.1177/2158244018824506

2. Adebayo, F. A. (2015). Time management and students academic performance in higher institutions, nigeria a case study of ekiti state. International Research in Education, 3(2), 1-12. https://doi.org/10.5296/ire.v3i2.7126

3. Adeel, S. (2018). The Impact of Impact of Hostel Environment on Students' Academic Performance (BBA), Sukkur IBA University, Sukkur, Pakistan. (143-14-0005)

4. Ahmad, S., Shahid, M., \& Banu, S. (2018). Hostel Life and Educational Performance: A Comparative Study of University Students, Pakistan. International Journal of Research in Humanities and Social Studies, 5(4), 31-35.

5. Akcoltekin, A. (2015). High School Students' Time Management Skills in Relation to Research Anxiety. Educational Research and reviews, 10(16), 2241-2249. https://doi.org/10.5897/ERR2015.2345

6. Al-Zoubi, M. (2016). The Effect of the Time Management Art on Academic Achievement among High School Students in Jordan. Journal of Education and Practice, 7(5), 158-167.

7. Al Khatib, A. S. (2014). Time management and its relation to students' stress, gender and academic achievement among sample of students at Al Ain University of science and technology, UAE. International Journal of Business and Social Research, 4(5), 47-58.

8. Alghaswyneh, O. F. M., \& Basri, W. S. (2015). The Role of Time Management and its Impact on Students' Academic Achievement A Case (Students at Northern Borders University). International Research Journal of Finance and Economics(136), 117-125.

9. Britton, B. K., \& Tesser, A. (1991). Effects of time-management practices on college grades. Journal of educational psychology, 83(3), 405. https://doi.org/10.1037/0022-0663.83.3.405

10. Chanamarn, N., \& Tamee, K. (2017). Enhancing Efficient Study Plan for Student with Machine Learning Techniques. International Journal of Modern Education and Computer Science, 9(3), 1-9. https://doi.org/10.5815/ijmecs.2017.03.01

11. Chang, S.-H., Liu, H.-C., \& Lin, K.-H. (2013). A Study on the Internet Addiction of the Junior High School Students. Paper presented at the The International Conference on E-Technologies and Business on the Web (EBW2013)(EBW2013), Thailand.

12. Claessens, B. J., Van Eerde, W., Rutte, C. G., \& Roe, R. A. (2007). A review of the time management literature. Personnel review, 36(2), 255-276. https://doi.org/10.1108/00483480710726136

13. Cyril, A. V. (2015). Time Management and Academic Achievement of Higher Secondary Students. Journal on School Educational Technology, 10(3), 38-43. https://doi.org/10.26634/jsch.10.3.3129

14. Dahie, A. M., Osman, A. A., \& Mohamed, R. A. (2015). Time Management and Academic Performance: Empirical Survey from High Education in Mogadishu-Somalia. International Journal in Management and Social Science (IJMSS), 3(12), 376-388.

15. Dalli, M. (2014). The university students time management skills in terms of their academic life satisfaction and academic achievement levels. Educational Research and reviews, 9(20), 1090-1096. https://doi.org/10.5897/ERR2014.1885 
16. DeFauw, C., Levering, K., Msipa, R. T., \& Abraham, S. (2018). Families' Support and Influence on College Students' Educational Performance. Journal of Education and Development, 2(1), 11. https://doi.org/10.20849/jed.v2i1.312

17. Eid, N. M., Safan, S. M., \& Diab, G. M. (2015). The effect of time management skills and self esteem of students on their grade point averages (GPA). IOSR Journal of Nursing and Health Science, 4(1), 82-88.

18. El Khatib, M., \& Khan, F. R. (2017). Implications of Social Media Networks Technology in Interpersonal Skills and Academic Performances. International Journal of Management, Innovation \& Entrepreneurial Research, 3(2), 99-110. https://doi.org/10.18510/ijmier.2017.326

19. Erdemir, M., \& Tomar, H. (2019). The influence of time management behaviours before starting general physics laboratory-I experiments on academic achievement in the course. Cypriot Journal of Educational Sciences, 14(3), 457-470. https://doi.org/10.18844/cjes.v14i3.4133

20. Forbus, P., Newbold, J., \& Mehta, S. (2011). University commuter students: Time management, stress factors and coping strategies. Advances in Business Research, 1(1), 142-151.

21. Gayef, A., Tapan, B., \& Sur, H. (2017). Relationship Between Time Management Skills and Academic Achievement of The Students in Vocational School of Health Services. Hacettepe Sağllk İdaresi Dergisi, 20(2), 219-246.

22. Goodson, C. E., Miertschin, S. L., \& Stewart, B. L. (2016). Time Management Skills and Student Performance in Online Courses The ASEE Computers in Education (CoED) Journal, 7(2), 37.

23. Hamdan, A., Nasir, R., Khairudin, R., \& Sulaiman, W. S. W. (2014). Time management does not matter for academic achievement unless you can cope. International Proceedings of Economics Development and Research, 78, 22. https://doi.org/10.1037/e627722013-261

24. Hamzah, A. R., Lucky, E. O.-I., \& Joarder, M. H. R. (2014). Time Management, External Motivation, and Students' Academic Performance: Evidence from a Malaysian Public University. Asian Social Science, 10(13), 55. https://doi.org/10.5539/ass.v10n13p55

25. Hensley, L. C., Wolters, C. A., Won, S., \& Brady, A. C. (2018). Academic probation, time management, and time use in a college success course. Journal of College Reading and Learning, 48(2), 105-123. https://doi.org/10.1080/10790195.2017.1411214

26. Herrera Agudelo, L. F. (2016). Students' Performance in Class through an Effective Time Management Implementing Productive Lesson Planning. (Bachelor of Education in Teaching Foreign Languages Thesis), Universidad de Antioquia, Medellin, Antioquia. Retrieved from http://bibliotecadigital.udea.edu.co/dspace/bitstream/10495/10701/1/HerreraLuisa_2016_PerformanceClassEffectiv e.pdf

27. Iftikhar, A., \& Ajmal, A. (2015). A qualitative study investigating the impact of hostel life. International Journal of Emergency Mental Health and Human Resilience, 17(2), 511-515. https://doi.org/10.4172/1522-4821.1000204

28. Indreica, E.-S., Cazan, A.-M., \& Truta, C. (2011). Effects of learning styles and time management on academic achievement. Procedia-Social and Behavioral Sciences, 30(1), 1096-1102. https://doi.org/10.1016/j.sbspro.2011.10.214

29. Karakose, T. (2015). The Relationship between Medical Students' Time Management Skills and Academic Achievement. Studies on Ethno-Medicine, 9(1), 19-24. https://doi.org/10.1080/09735070.2015.11905418

30. Kayode, G., \& Ayodele, J. (2015). Impacts of teachers' time management on secondary school students' academic performance in Ekiti State, Nigeria. International Journal of Secondary Education, 3(1), 1-7. https://doi.org/10.11648/j.ijsedu.20150301.11

31. Khanam, N., Sahu, T., Rao, E., Kar, S., \& Quazi, S. Z. (2017). A Study on University Student's Time Management and Academic Achievement. International Journal Of Community Medicine And Public Health, 4(12), 4761-4765. https://doi.org/10.18203/2394-6040.ijcmph20175365

32. Khurshid, F., Tanveer, A., \& Qasmi, F. N. (2012). Relationship between study habits and academic achievement among hostel living and day scholars' university students. British Journal of Humanities and Social Sciences, 3(2), 34-42.

33. Li, Z., \& Qiu, Z. (2018). How does family background affect children's educational achievement? Evidence from Contemporary China. The Journal of Chinese Sociology, 5(1), 13. https://doi.org/10.1186/s40711-018-0083-8

34. Lin, M., Pan, C., \& Ching, G. (2015). Common problems and coping solutions of university students in Taiwan. International Journal of Research Studies in Education, 4(1), 3-16. https://doi.org/10.5861/ijrse.2014.717

35. Macan, T. H., Shahani, C., Dipboye, R. L., \& Phillips, A. P. (1990). College students' time management: Correlations with academic performance and stress. Journal of educational psychology, 82(4), 760. https://doi.org/10.1037//0022-0663.82.4.760 
36. Mansoor, U., \& Hussain Ali, M. (2015, Dec. 2015). Impact of hostel students' satisfaction on their academic performance in Sri Lankan universities. Paper presented at the Emerging trends and challenges in multidisciplinary research - 5th International Symposium, South Eastern University of Sri Lanka, Oluvil, Sri lanka.

37. McDaniel, B. T. (2019). Parent distraction with phones, reasons for use, and impacts on parenting and child outcomes: A review of the emerging research. Human Behavior and Emerging Technologies, 1(2), 72-80. https://doi.org/10.1002/hbe2.139

38. Mercanlioglu, Ç. (2010). The relationship of time management to academic performance of master level students. International Journal of Business and Management Studies, 2(1), 25-36.

39. Miqdadi, F., ALMomani, A., Masharqa, M. S., \& Elmousel, N. (2014). The relationship between time management and the academic performance of students from the petroleum institute in Abu Dhabi, the UAE. Paper presented at the ASEE 2014 Zone I Conference.

40. Mohamed, O., Hamal, R. B., \& Mohamed, K. (2018). A Study on Time Management: Case of NorthEast Normal University International Students European Journal of Alternative Education Studies, 3(1), 17-30.

41. Nasrullah, S., \& Khan, F. R. (2019). Examining the Impact of Social Media on the Academic Performances of Saudi Students-Case Study: Prince Sattam Bin Abdul Aziz University. Humanities \& Social Sciences Reviews, 7(5), 851-861. https://doi.org/10.18510/hssr.2019.75111

42. Nasrullah, S., \& Khan, M. S. (2015). The impact of time management on the students' academic achievements. Journal of Literature, Languages and Linguistics, 11, 66-71.

43. Nonis, S. A., \& Hudson, G. I. (2006). Academic performance of college students: Influence of time spent studying and working. Journal of education for business, 81(3), 151-159. https://doi.org/10.3200/JOEB.81.3.151-159

44. Nzewi, H., Chiekezie, O., \& Ikon, M. A. (2016). Time Management and Academic Performance of Postgraduate Students in Nigerian Universities. Review of public administration \& management, $1(2)$. https://doi.org/10.4172/2315-7844.1000110

45. Office of the Famly Engagement. (2019). Time Management and Overcommitment [Daily DAEC Blog]. Retrieved from https://parents.wfu.edu/family-messages/time-management-and-overcommitment/

46. Olowookere, E. I., Alao, A. A., Odukoya, A., Adekeye, O. A., \& Agbude, G. (2015). Time management practices, character development and academic performance among University Undergraduates: covenant university experience. Creative Education, 6, 79-86. https://doi.org/10.4236/ce.2015.61007

47. Oyuga, P. A., Raburu, P. A., \& Aloka, P. J. (2016). Relationship between Time management and academic performance among orphaned secondary School students of Kenya. International Journal of Applied Psychology, 6(6), 171-178. doi: http://doi.org/10.5923/j.ijap.20160606.02

48. Pehlivan, A. (2013). The effect of the time management skills of students taking a financial accounting course on their course grades and grade point averages. International Journal of Business and Social Science, 4(5), 196-203.

49. Rai, A. (2016). A Study of Impact of Time Management on Academic Performance of Students Studying in School. PARIPEX-Indian Journal of Research, 5(6), 149-150.

50. Razali, S., Rusiman, M., Gan, W., \& Arbin, N. (2017, 28-29 October 2017). The impact of time management on students' academic achievement. Paper presented at the International Seminar on Mathematics and Physics in Sciences and Technology 2017 (ISMAP 2017) Hotel Katerina, Malaysia.

51. Sikhakhane, A. P.-J. (2019). Effects of Time Management on the Pass Rate of Undergraduate and Postgraduate Office Management and Technology Students. Durban University of Technology.

52. Swart, A. J., Lombard, K., \& de Jager, H. (2010). Exploring the relationship between time management skills and the academic achievement of African engineering students-a case study. European Journal of Engineering Education, 35(1), 79-89. https://doi.org/10.1080/03043790903480316

53. Thibodeaux, J., Deutsch, A., Kitsantas, A., \& Winsler, A. (2017). First-year college students' time use: Relations with self-regulation and GPA. Journal of Advanced Academics, 28(1), 5-27. https://doi.org/10.1177/1932202X16676860

54. Twehues, A. (2013). Success and the Balance of Commitment and Time: Effects of Perceived Time Management Control on College Student Performance.

55. Wells, G. D. (1994). Time-management and academic achievement. (M.A. Master Thesis), University of Windsor, Ottawa, Canada. Retrieved from http://scholar.uwindsor.ca/etd/4393

56. Yörük, A., Boyraz, A., Akkuş, H., \& Akkuş, A. (2012). Effect of Families on Students' Achievement and Success on Science Courses. International Journal of Arts and Sciences, 5(1), 119-125.

57. Zakaria, G. A. (2016). Hostels and academic performance of girls in community secondary schools in Tanzania: the case of Ikungi district, Tanzania. Mzumbe University.

58. Zartler, U. (2010). No Time for the Family-Time Management as Being Seen by Children and their Parents. SWSRUNDSCHAU, 5O(4), 463-473. 
59. Zotorvie, J. (2017). Students' Accommodation and Academic Performance: The Case of Ho Technical University, Ghana. European Scientific Journal, 13(13), 290-302.

60. Zulauf, C. R., \& Gortner, A. K. (1999). Use of time and academic performance of college students: does studying matter? 